\title{
ANALISIS PENYUSUNAN ANGGARAN PENDAPATAN BELANJA DAERAH (APBD) BERBASIS KINERJA DI SKPD PROVINSI BENGKULU
}

\author{
Yetti Afrida Indra
}

Febi IAIN Bengkulu

\section{Yetti_afrida@iainbengkulu.ac.id}

Abstract: This study aims to examine empirically and analyze whether the performancebased Bengkulu Provincial SKPD budgeting is analyzed from the commitment factors of all organizational components, improving the administration system, sufficient resources, clear rewards and firm penalties / sanctions. This study uses questionnaires in data collection. The sampling method in this study was people who were directly involved in budgeting in the agency/work unit within the Bengkulu provincial governmentThe results of the first hypothesis study show that the performance-based budgeting has a significant effect on commitment. This identifies that high commitment will affect the success of performance-based budgeting. The second hypothesis shows that performancebased budgeting has a significant effect on the administration system. The results of the third hypothesis study show that performance-based budgeting does not affect resources. The results of the fourth hypothesis study that performance-based budgeting has no significant effect on rewards. For the fifth hypothesis shows that performance-based budgeting has a significant effect on sanctions

Keywords:Budgeting, Performance Based APBD, Commitment, Administrative System, Resources, Awards, Sanctions, and Motivation.

\section{PENDAHULUAN}

Reformasi sektor publik salah satunya ditandai oleh munculnya era New Public Management (NPM) yang telah mendorong usaha untuk mengembangkan pendekatan yang lebih sistematis dalam perencanaan anggaran sektor publik. Seiring dengan perkembangan tersebut, muncul beberapa teknik penganggaran sektor publik, misalnya adalah teknik anggaran kinerja (Performance Budgeting), Zero Based Budgeting $(Z B B)$, dan Planning, Programming, and Budgeting System (PPBS). Penganggaran merupakan rencana keuangan yang secara sistimatis menunjukkan alokasi sumber daya manusia, material, dan sumber daya 
lainnya. Berbagai variasi dalam sistem penganggaran

pemerintah

dikembangkan untuk melayani berbagai tujuan termasuk guna pengendalian keuangan, rencana manajemen, prioritas dari penggunaan dana dan pertanggungjawaban kepada publik. Penganggaran berbasis kinerja diantaranya menjadi jawaban untuk digunakan sebagai alat pengukuran dan pertanggungjawaban kinerja pemerintah.

Penuangan rencana pembangunan dalam suatu dokumen perencanaan nasional lima tahun di Indonesia yang ditetapkan dengan undang-undang dirasakan tidak realistis dan semakin tidak sesuai dengan dinamika kebutuhan penyelenggaraan pemerintahan dalam era globalisasi.

Undang-undang Nomor 32 Tahun 2004 tentang Pemerintah Daerah dan Undang-undang Nomor 33 Tahun 2004 tentang perimbangan Keuangan antara Pemerintah Pusat dan Pemerintah Daerah membuka peluang yang besar bagi Daerah untuk mengembangkan dan membangun Daerahnya sesuai dengan kebutuhan dan prioritas masingmasing. Dengan berlakunya undangundang tersebut membawa konsekuensi bagi daerah dalam bentuk pertanggungjawaban atas pengalokasian dana yang dimiliki dengan cara yang efisien dan efektif , khususnya dalam upaya peningkatan kesejahteraan dan pelayanan umum kepada masyarakat. Dengan menyusun rencana kerja dan anggaran satuan kerja perangkat daerah (RKA- SKPD) sesuai dengan undang-undang Nomor 17 tahun 2003 tentang keuangan negara pasal 19 (1) dan (2) yang berbunyi pendekatan berdasarkan prestasi kerja yang akan dicapai.

Penganggaran berbasis kinerja merupakan metode penganggaran bagi manajemen untuk mengaitkan setiap pendanaan yang dituangkan dalam kegiatan-kegiatan dengan keluaran dan hasil yang diharapkan, termasuk efisiensi dalam pencapaian hasil dari keluaran tersebut. Keluaran dan hasil tersebut dituangkan dalam target kinerja pada setiap unit kerja. Sedangkan bagaimana tujuan itu dicapai, dituangkan dalam program, diikuti dengan pembiayaan pada setiap tingkat pencapaian tujuan.

Dalam kegiatan perencanaan dan penganggaran yang melibatkan seluruh unsur pelaksana yang ada di Satuan Kerja Perangkat Daerah (SKPD) mulai dari penentuan program 
dan kegiatan, klasifikasi belanja, penentuan standar belanja, penentuan standar biaya, penentuan indikator kinerja dan target kinerja, sampai dengan jumlah anggaran yang harus disediakan, memerlukan perhatian yang serius bagi pimpinan satuan kerja perangkat daerah beserta pelaksana program dan kegiatan. Dokumen anggaran harus dapat menyajikan informasi yang jelas tentang tujuan, sasaran serta korelasi antara besaran anggaran dengan manfaat dan hasil yang ingin dicapai dari suatu kegiatan yang dianggarkan.

\subsection{Rumusan Masalah}

Berdasarkan latar belakang diatas maka dapat dirumuskan masalah sebagai berikut :

1) Apakah penyusunan APBD berbasis kinerja bepengaruh terhadap Komitmen?

2) Apakah penyusunan APBD berbasis kinerja berpengaruh terhadap sistem administrasi?

3) Apakah penyusunan APBD berbasis kinerja sumberdaya berpengaruh terhadap?

4) Apakah penyusunan APBD berbasis kinerja berpengaruh terhadap ?
5) Apakah penyusunan APBD berbasis kinerja berpengaruh terhadap sanksi?

6) Apakah penyusunan APBD berbasis kinerja berpengaruh terhadap motivasi?

\subsection{Tujuan Penelitian}

Berdasarkan latar belakang dan rumusan masalah maka tujuan penelitian ini adalah :

1) Untuk mengetahui dan menganalisis pengaruh penyusunan APBD berbasis kinerja terhadap Komitmen.

2) Untuk mengetahui dan menganalisis pengaruh penyusunan APBD berbasis kinerja terhadap sistem administrasi.

3) Untuk mengetahui dan menganalisis pengaruh penyusunan APBD berbasis kinerja terhadap sumberdaya.

4) Untuk mengetahui dan menganalisisi pengaruh penyusunan APBD berbasis kinerja terhadap penghargaan.

5) Untuk mengetahui dan menganalisis pengaruh penyusunan APBD berbasis kinerja terhadap sanksi. 
6) Untuk mengetahui pengaruh Penyusunan APBD berbasis kinerja terhadap motivasi.

\subsection{Manfaat Penelitian}

1). Bagi Peneliti untuk menambah wawasan peneliti khususnya tentang faktor-faktor yang mempengaruhi penerapan penganggaran berbasis kinerja dalam penyusunan APBD .

2). Bagi Pemerintah Daerah Provinsi Bengkulu, penelitian ini dapat sebagai bahan informasi tambahan atau masukan dan sebagai pertimbangan pejabat pemerintah daerah baik eksekutif mauapun legislatif untuk melakukan penyempurnaan dan perbaikan penyusunan anggaran untuk mencapai visi dan misi Kepala Daerah.

3). Bagi Akademisi Penelitian ini dapat memperkaya hasil penelitian dan referensi bagi para akademisi sebagai saran pengembangan bidang anggaran berbasis kinerja.

2. KAJIAN PUSTAKA, KERANGKA PEMIKIRAN DAN HIPOTESIS

\subsection{Pengertian Anggaran}

Proses penyusunan anggaran seringkali menjadi isu penting yang menjadi sorotan masyarakat . Misalnya pidato presiden setiap bulan Agustus tentang Nota Keuangan dan Rancangan APBN selalu menjadi indikator perekonomian setahun ke depan. Bahkan tidak jarang APBN tersebut menjadi alat politik yang digunakan, baik oleh pemerintah sendiri maupun pihak oposisi. Anggaran Negara merupakan rencana keuangan pemerintah dalam suatu waktu tertentu, biasanya dalam satu tahun mendatang, yang satu pihak memuat jumlah pengeluaran setinggi-tingginya untuk membiayai tugas-tugas negara di segala bidang, dan di lain pihak memuat jumlah penerimaan negara yang diperkirakan dapat menutup pengeluaran tersebut dalam periode yang sama.

Penganggaran memiliki tiga tujuan utama yang saling terkait yaitu stabilitas fiskal makro,alokasi sumber daya sesuai prioritas, dan pemanfaatan anggaran secara efektif dan efisien. Sebagai instrumen kebijakan ekonomi anggaran berfungsi untuk mewujudkan pertumbuhan ekonomi, stabilitas ekonomi, dan pemerataan pendapatan. Anggaran negara juga berfungsi sebagai alat perencanaan dan 
pengawasan aktivitas pemerintahan.

Anggaran berasal dari kata budget (Inggris), sebelumnya dari kata bougette (Prancis) yang berarti sebuah kas kecil. Berdasarkan dari arti kata asalnya, anggaraan mencerminkan adanya unsur keterbatasan. Pada dasarnya anggaran perlu disusun karena keterbatasan sumber daya yang dimiliki pemerintah, dalam hal ini dana. Karena terbatasnya dana, maka diperlukan alokasi sesuai dengan prioritas dan dalam kurun waktu yang telah ditentukan. Anggaran negara (state budget) menurut Jhon F. Due (2000) dalam "Government Finance and Economic Analysis" adalah "A budget, in the general sense of the term, is a financial plan for a specific period of time. A government budget therefore, is a statement of proposed expenditures and expected revunue for the coming period, together with data of actual expenditures and revenues for current and past period".

Menurut Wildavsky (1975), anggaran adalah: (a) catatan masa lalu, (b) rencana masa depan, (c) mekanisme pengalokasian sumber daya,

(d) metode untuk pertumbuhan, (e) alat penyaluran pendapatan, (f) mekanisme untuk negosiasi, (g) harapan-aspirasi-strategi organisasi, (h) satu bentuk kekuatan kontrol, dan (i) alat atau jaringan komunikasi.

Berdasarkan pengertianpengertian di atas, anggaran negara/daerah meliputi:

1) Rencana keuangan mendatang yang berisi pendapatan dan belanja

2) Gambaran strategi pemerintah dalam pengalokasian sumber daya untuk pembangunan

3) Alat pengendalian

4) Instrumen politik, dan

5) Disusun dalam periode tertentu

\subsection{Anggaran Berbasis Kinerja}

Deputi IV BPKP (2010) mengemukakan penganggaran merupakan rencana keuangan yang secara sistimatis menunjukkan alokasi sumber daya manusia, material, dan sumber daya lainnya. Berbagai variasi dalam sistem penganggaran pemerintah dikembangkan untuk melayani berbagai tujuan termasuk guna pengendalian keuangan, rencana manajemen, prioritas dari penggunaan dana dan pertanggungjawaban kepada publik.

Penganggaran berbasis kinerja 
merupakan metode penganggaran bagi manajemen untuk mengaitkan setiap pendanaan yang dituangkan dalam kegiatan-kegiatan dengan keluaran dan hasil yang diharapkan termasuk efisisiensi dalam pencapaian hasil dari keluaran tersebut. Keluaran dan hasil tersebut dituangkan dalam target kinerja pada setiap unit kerja. Sedangkan bagaimana tujuan itu dicapai, dituangkan dalam program diikuti dengan pembiayaan pada setiap tingkat pencapaian tujuan.

Menurut Bastian (2006) anggaran kinerja adalah perencanaan kinerja tahunan secara terintegrasi yang menunjukkan hubungan antara tingkat pendanaan program dan hasil yang diinginkan dari program tersebut. Anggaran dengan pendekatan kinerja adalah suatu sistem anggaran yang menutamakan upaya pencapaian hasil kerja atau output dari perencanaan alokasi biaya atau input yang ditetapkan. Anggaran kinerja yang efektif lebih dari sebuah anggaran program atau organisasi dengan outcome yang telah diantisipasi. Hal ini akan menjelaskan hubungan biaya (Rp) dengan hasil (result).

Baswir (2002) mengemukakan bahwa penyusunan anggaran berdasarkan suatu struktur dan klasifikasi tertentu adalah suatu langkah penting untuk mendapatkan sistem penganggaran yang baik dan berfungsi sebagai pedoman bagi pemerintah dalam mengelola negara, sebagai alat pengawas bagi masyarakat terhadap kebijakan dan kemampuan pemerintah. Penyusunan anggaran tidak bisa dilepaskan dari karakteristik suatu daerah, untuk dijadikan sebagai dasar pertimbangan dalam pengalokasian anggaran.

\subsection{Tahapan Penyusunan Rancangan APBD}

Berdasarkan Undang-Undang No. 17 Tahun 2003 serta Undang-Undang No. 32 dan 33 Tahun 2004, penyusunan rancangan Anggaran Pendapatan dan Belanja Daerah (APBD) secara keseluruhan yang mencakup penyusunan Kebijakan Umum APBD sampai dengan disusunnya Rancangan APBD terdiri dari beberapa tahapan sebagai berikut:

1) Pemerintah daerah menyampaikan kebijakan umum APBD tahun anggaran berikutnya sebagai landasan penyusunan rancangan APBD paling lambat pada pertengahan bulan Juni tahun berjalan. Kebijakan umum APBD 
tersebut berpedoman pada RKPD.

Proses penyusunan RKPD tersebut dilakukan antara lain dengan melaksanakan musyawarah perencanaan pembangunan (musrenbang) yang selain diikuti oleh unsur-unsur pemerintahan juga mengikutsertakan dan/atau menyerap aspirasi masyarakat terkait, antara lain asosiasi profesi, perguruan tinggi, lembaga swadaya masyarakat (LSM), pemuka adat, pemuka agama, dan kalangan dunia usaha.

2) DPRD kemudian membahas kebijakan umum APBD yang disampaikan oleh pemerintah daerah dalam pembicaraan pendahuluan RAPBD tahun anggaran berikutnya.

3) Berdasarkan Kebijakan Umum APBD yang telah disepakati dengan DPRD, pemerintah daerah bersama DPRD membahas prioritas dan plafon anggaran sementara untuk dijadikan acuan bagi setiap SKPD.

4) Kepala SKPD selaku pengguna anggaran menyusun RKA-SKPD tahun berikutnya dengan mengacu pada prioritas dan plafon anggaran sementara yang telah ditetapkan oleh pemerintah daerah bersama DPRD.

5) RKA-SKPD tersebut kemudian disampaikan kepada DPRD untuk dibahas dalam pembicaraan pendahuluan RAPBD.

6) Hasil pembahasan RKA-SKPD disampaikan kepada pejabat pengelola keuangan daerah sebagai bahan penyusunan rancangan perda tentang APBD tahun berikutnya.

7) Pemerintah daerah mengajukan rancangan perda tentang APBD disertai dengan penjelasan dan dokumen-dokumen pendukungnya kepada DPRD pada minggu pertama bulan Oktober tahun sebelumnya.

8) Pengambilan keputusan oleh DPRD mengenai rancangan perda tentang APBD dilakukan selambat-lambatnya satu bulan sebelum tahun anggaran yang bersangkutan dilaksanakan.

\subsection{Standar Analisa Belanja}

Selain proses penyusunan yang harus melibatkan banyak pihak, kriteria APBD yang disusun berdasarkan anggaran kinerja adalah 
dikembangkannya Standar Analisa Belanja (SAB), yang digunakan untuk menilai kewajaran beban kerja dan biaya setiap program atau kegiatan yang akan dilaksanakan oleh unit kerja dalam satu tahun anggaran. Peraturan Pemerintah Nomor 105 tahun 2000 tentang Pengelolaan dan Pertanggungjawaban Keuangan Daerah, pasal 20 (1) b menyatakan bahwa APBD yang disusun dengan pendekatan kinerja memuat standar pelayanan yang diharapkan dan perkiraan biaya satuan komponen kegiatan yang bersangkutan; Ayat (2) menyatakan bahwa untuk mengukur kinerja keuangan pemerintah daerah dikembangkan Standar Analisa Belanja, Tolok Ukur Kinerja dan Standar Biaya.

Standar Analisa Belanja (SAB) adalah standar untuk menganalisis anggaran belanja yang digunakan dalam suatu program atau kegiatan untuk menghasilkan tingkat pelayanan tertentu sesuai dengan kebutuhan masyarakat. SAB digunakan untuk menilai kewajaran beban kerja dan biaya setiap program atau kegiatan yang akan dilaksanakan oleh unit kerja dalam satu tahun anggaran.

\subsection{Faktor-faktor yang}

mempengaruhi Penyusunan

\section{APBD Berbasis Kinerja}

\subsubsection{Komitmen Organisasi}

Menurut Wahono (2001), Kepemimpinan sebagai suatu proses dan perilaku untuk mempengaruhi aktivitas para anggota kelompok untuk mencapai tujuan bersama yang dirancang untuk memberikan manfaat individu dan organisasi. Komitemn dari seluruh komponen organisasi pemerintah daerah adalah kesepakatan antara kepala satuan kerja perangkat daerah beserta seluruh komponen organisasi dalam melaksanakan tugas pokok dan fungsi organisasinya untuk keberhasilan melaksanakan visi,misi,tujuan, sasaran sesuai dengan Renstra SKPD . Mowday,Poster, dan Steers (1982) mendifinisikan Komitmen Organisasi sebagai: the relative strength of an individua's identification with and involvement in particuler organization. Definisi ini menunjukkan bahwa komitmen organisasi memiliki arti lebih dari sekedar loyalitas yang pasif, tetapi melibatkan hubungan aktif dan keinginan karyawan untuk memberikan kontribusi yang berarti pada organisasinya.

Adapun menurut Robbins dan 
Coulter mengatakan bahwa "Organizational commitment is the degree to which an employee identifies with a particular organization and its goals and wishes to maintain membership in organization”. Dengan kata lain, komitmen organisasi adalah tingkat sejauh mana identifikasi karyawan terhadap suatu organisasi dan tujuannya dan keinginan untuk mempertahankaan keanggotaan pada organisasi tersebut.

Mowday (1982) mendefinisikan komitmen sebagai kekuatan relatif dari identifikasi individu dan keterlibatannya sebagai kekuatan relative dari identifikasi individu dengan organisasi kerja. Sedangkan Mitchell (1982) memandang komitmen sebagai suatu orientasi nllai terhadap kerja yang menunjukkan bahwa individu sangat memikirkan pekerjaannya. Dimana pekerjaan memberikan kepuasan hidup, dan pekerjaan memberikan status bagi indvidu.

$$
\text { Charles o'Reilly }
$$
menyatakan bahwa komitmen organisasi secara umum dipahami sebagai ikatan ejiwaan individu terhadap organisasi termasuk keterlibatan kerja, kesetiaan dan perasaan percaya pada nilai-nlai oganisasi. Komitmen organisasi melebihi pengertian dari loyalitas untuk memberikan konstribusi yang aktif mencapai tujuan orgaisasi. Komitmen organisasi mewakili sebuah sikap kerja yang lebih luas dibandingkan kepuasan kerja, karena komitmen organisasi aplikasinya lebih meyeluruh pada organisasi dibandingkan hany pada pekerjaan saja. Lebih lanjut, dikatakan bahwa komitmen lebih stabil dibandingkan kepuasan kerja karena kejadian dari hari-kehari hanya sedikit mempengaruhi perubahan komitmen.

\subsubsection{Sistem Administrasi}

Wajah administasi suatu negara merupakan produk dari sistem politik, posisi perkembangan ekonomi dan sosial dari negara yang bersangkutan, di samping sebaliknya dalam banyak hal administrasi negara juga menentukan penampilan sistem politik, perkembangan ekonomi dan kualitas sosial negara itu. Oleh karena itu seharusnya pembahasan tentang sejarah administrasi negara Republik Indonesia ini dilakukan dan bersamaan dengan pembahasan tentang sejarah pemerintahan dan politik.

$$
\text { Teori sistem merupakan }
$$
kerangka konseptual atau satu cara 
pendekatan yang dipergunakan untuk menganalisis lingkungan atau gejala yang bersifat kompleks dan dinamis. Pendekatan sistem, pertama melihat sesuatu secara keseluruhan. Baru kemudian mengamati bagianbagiannya (sub-subsistem); di mana bagian-bagian (sub-subsistem) itu saling melakukan interaksi dan interrelasi.

Penyimpangan praktik administrasi atau maladministrasi yang ditandai dengan menurunnya atau tiadanya disiplin, ketekunan, ketelitian, kecermatan dan semangat kerja yang disebabkan oleh beberapa sebab, diantaranya:

1) Situasi transisi menciptakan ketidaknyamanan dan ketidakamanan kerja, sehingga kebanyakan pegawai "menyelamatkan diri sendiri";

2) Pejabat yang duduk di dalam birokrasi kebanyakan adalah pejabat lama yang sebelumnya merupakan pegawai Hindia Belanda, yang berorientasi bukan kepada prestasi melainkan askripsi;

3) Masih sangat sedikitnya jumlah profesional modern yang dapat ditarik ke dalam birokrasi.

Suatu usaha untuk menerapkan ide baru dalam system administrasi, serta dengan sadar memperbaiki system tersebut bagi pencapaian tujuan \& sasaran pembangunan yg positif (Haka Been Lee).

Ada 3 unsur yang membedakan upaya penyempurnaan administrasi dengan perubahan lainnya:

1) Kepentingan moral: menghilangkan cara yang salah di bidang administrasi.

2) Perubahan terarah: sekali penyempurnaan dilakukan maka diusahakan penyempurnaan itu bersifat permanen..

3) Ketahanan administrasi: perlu ada dukungan politik agar perubahan status quo berjalan lancar.

Faktor yang Mempengaruhi Penyempurnaan Administrasi:

1) Keadaan perubahan: tujuan, sasaran.

2) Agen pembaharu: orang yg melakukan perubahan.

3) Faktor lingkungan: kondisi negara tersebut.

Berhasilnya penyempurnaan administrasi tergantung dari berapa 
banyak jumlah orang yang berpartisipasi secara langsung atau tidak langsung dalam proses perubahan yg dilaksanakan.

\section{Menurut Bintaro}

penyempurnaan administrasi berarti perubahan langsung keseluruh administrasi untuk mencapai tujuan masyarakat yang menyeluruh yaitu modernisasi. Penyempurnaan administrasi merupakan suatu usaha yang sengaja dilakukan untuk menambah struktur dan prosedur birokrasi pemerintah, sikap dan tindakan aparat birokrasi atau keduaduanya supaya dapat meningkatkan efektifitas organisasi dan mencapai tujuan pembangunan nasional. Kesimpulannya penyempurnaan administrasi merupakan penyajian instrumen pengukuran anggaran berbasis kinerja secara terus menerus.

\subsubsection{Sumber Daya Manusia}

Menurut Nawawi (2001) ada tiga pengertian Sumber daya manusia yaitu:

1) Sumber daya manusia adalah manusia yang bekerja dilingkungan suatu organisasi (disebut juga personil, tenaga kerja, pekerja atau karyawan).

2) Sumber daya manusia adalah potensi manusiawi sebagai penggerak organisasi dalam mewujudkan eksistensinya.

3) Sumber daya manusia adalah potensi yang merupakan aset dan berfungsi sebagai modal (non material/non finansial) di dalam organisasi bisnis, yang dapat mewujudkan menjadi potensi nyata (real) secara fisik dan non-fisik dalam mewujudkan eksistensi organisasi.

Berdasarkan pengertian tersebut dapat disimpulkan bahwa sumber daya manusia adalah suatu proses mendayagunakan manusia sebagai tenaga kerja secara manusiawi, agar potensi fisik dan psikis yang dimilikinya berfungsi maksimal bagi pencapaian tujuan organisasi (lembaga).

Disamping itu, manusia adalah makhluk Tuhan yang kompleks dan unik serta diciptakan dalam integrasi dua substansi yang tidak berdiri sendiri yaitu tubuh ( fisik /jasmani) sebagai unsur materi, dan jiwa yang bersifat non materi. Hubungan kerja yang paling intensif dilingkungan organisasi adalah antara pemimpin dengan para pekerja (staf) yang ada di bawahnya.

Hubungan kerja semakin penting 
artinya dalam usaha organisasi mewujudkan eksistensinya dilingkungan tugas yang lebih luas dan kompetetif pada masa yang akan datang.

Sumber daya manusia memiliki keinginan, harga diri, pikiran, hak asasi, ingin dihormati dan lain-lain. Oleh karena itu sumber daya manusia harus diperlakukan sama secara hatihati dan penuh kearifan.

Sumber daya manusia adalah ujung tombak pelayanan, sangat diandalkan untuk memenuhi standar mutu yang diinginkan oleh wajib pajak dan wajib retribusi. Untuk mencapai standar mutu tersebut, maka harus diciptakan situasi yang mendukung pelayanan yang memuaskan wajib pajak dan wajib retribusi.

Upaya-upaya manusia itu bukan sesuatu yang statis, tetapi terus berkembang dan berubah, seirama dengan dinamika kehidupan manusia, yang berlangsung dalam kebersamaan sebagai suatu masyarakat. Oleh karena itu salah satu situasi yang mendukung adalah seluruh peraturan pengelolaan sumber daya manusia yang berdampak pada perlakuan yang sama kepada pegawai.
Pada dasarnya kebutuhan umum yang dituntut oleh manusia terdiri dari dua macam, yaitu kebutuhan material dan kebutuhan spritual. Pembagian kebutuhan seperti ini terlalu umum untuk dijadikan pedoman dalam memotivasi bawahan.

Oleh karena itu, Maslow (dalam Siagian, 1981) menyebutkan 5 tingkatan kebutuhan manusia, yang secara umum dapat dijelaskan sebagi berikut :

a) Kebutuhan Fisiologis (Physiological Needs), yang termasuk dalam kebutuhan ini, misalnya sandang, pangan, papan, dan tempat berlindung. Kebutuhan ini termasuk kebutuhan primer dan mendesak sifatnya. Untuk itu seorang pimpinan yang ingin insruksi dan perintahnya dilaksanakan hendaknya dapat memenuhi kebutuhan tersebut.

b) Kebutuhan Keamanan (Safety Needs), yang termasuk dalam kebutuhan ini, misalnya kebutuhan akan keamanan jiwa terutama dalam jam-jam kerja.

c) Kebutuhan akan keamanan kantor ditempat kerja, termasuk jaminan hari tua. Kebutuhan social (social 
Needs), yang termasuk pada tingkatan kebutuhan ini, misalnya kebutuhan untuk dihormati, kebutuhan untuk bisa diterima dilingkungan kerja, keinginan untuk maju dan tidak ingin gagal, kebutuhan akan perasaan untuk turut serta memajukan organisasi.

d) Kebutuhan Prestise (Esteem Needs). Pada umumnya pegawai akan mempunyai prestise setelah mempunyai prestasi. Dengan demikian prestasi pegawai perlu diperhatikan oleh pimpinan organisasi. Biasanya, pegawai yang telah mempunyai prestasi yang lebih tinggi akan terus berupaya untuk meningkatkan prestasinya secara maksimal.

c) Kebutuhan mempertinggi kapasitas kerja (Self Actualization). Setiap karyawan pasti ingin mengembangkan kapasitas kerjanya secara optimal, misalnya melalui pendidikan latihan, seminar, dan sebagainya. Kebutuhan - kebutuhan untuk mengembangkan kapasitas kerja tersebut perlu mendapatkan perhatian pimpinan.

2.5.4 Penghargaan
Penghargaan adalah kegiatan dimana organisasi menilai kontribusi karyawan dalam rangka untuk mendistribusikan penghargaan moneter dan non moneter cukup langsung dan tidak langsung dalam kemampuan organisasi untuk membayar berdasarkan peraturan hukum (Schuler, 1987). Penghargaan adalah semua pendapatan yang berbentuk uang, barang langsung atau tidak langsung yang diterima karyawan sebagai imbalan atau jasa yang diberikan kepada perusahan (Hasibuan, 2007).

Nitisemito (1982) menyatakan bahwa penghargaan merupakan balas jasa yang diberikan oleh perusahaan kepada para karyawannya yang dapat dinilai dengan uang dan mempunyai kecenderungan diberikan secara tetap. Penghargaan berarti semua bentuk penggajian atau ganjaran kepada pegawai dan timbul karena kepegawaian mereka. Dapat berupa pembayaran uang secara langsung (upah, gaji, insentif, bonus) dan dapat pula berbentuk pembayaran tidak langsung (asuransi, liburan atas biaya perusahaan) dan dapat pula berupa ganjaran bukan uang (jam kerja yang luwes, kantor yang bergengsi, pekerjaan yang lebih menantang) 
(Dessler, 2005).

\section{Adapun faktor-faktor yang} mempengaruhi besarnya penghargaan, antara lain sebagai berikut (Hasibuan, 2007):

1) Penawaran dan permintaan tenaga kerja Jika pencari kerja (penawaran) lebih banyak dari pada lowongan pekerjaan (permintaan) maka penghargaan relatif sedikit. Sebaliknya jika pencari kerja lebih sedikit daripada lowongan pekerjaan, maka penghargaan relatif semakin banyak.

2) Kemampuan dan kesediaan organisasi Apabila kemampuan dan kesediaan organisasi untuk membayar semakin baik, maka tingkat penghargaan akan semakin meningkat. Tetapi sebaliknya, jika kemampuan dan kesedian organisasi untuk membayar kurang maka tingkat penghargaan relatif kecil.

3) Organisasi karyawan Apabila organisasi karyawan kuat dan berpengaruh maka tingkat penghargaan semakin besar. Sebaliknya jika organisasi karyawan tidak kuat dan kurang berpengaruh maka tingkat penghargaan relatif kecil.

4) Produktivitas kerja karyawan Jika produktivitas kerja karyawaan baik dan banyak maka penghargaan akan semakin besar. Sebaliknya kalau produktivitas kerjanya buruk serta sedikit maka penghargaannya kecil.

5) Pemerintah dengan UndangUndang dan Keppres Pemerintah dengan undang-undang dan keppres menetapkan besarnya penghargaan minimum. Peraturan pemerintah ini sangat penting supaya organisasi tidak sewenangwenang menetapkan besarnya penghargaan bagi karyawan. Pemerintah berkewajiban melindungi masyarakat dari tindakan sewenang-wenang.

6) Biaya hidup Apabila biaya hidup didaerah itu tinggi maka tingkat penghargaan semakin besar. Sebaliknya, jika tingkat biaya hidup di daerah itu rendah maka tingkat penghargaan relatif kecil.

7) Posisi jabatan karyawan Karyawan yang menduduki jabatan lebih tinggi akan menerima gaji/penghargaan lebih 
besar. Sebaliknya karyawan yang menduduki jabatan lebih rendah akan memperoleh gaji/penghargaan yang kecil.

8) Pendidikan dan pengalaman kerja Jika pendidikan lebih tinggi dan pengalaman kerja lebih lama maka penghargaan akan semakin besar, karena kecakapan serta keterampilannya lebih baik.

\subsubsection{Sanksi}

Menurut Nugroho (2006), Reward dan punishment merupakan dua bentuk metode dalam memotivasi seseorang untuk melakukan kebaikan dan meningkatkan prestasinya, dalam hal implementasi anggaran berbasis kinerja ini perlu dijaga konsistensi perencanaan dengan penganggaran dan pemberian reward dan punishment yang jelas bagi satuan kerja perangkat daerah. Program penghargaan penting bagi organisasi karena mencerminkan upaya organisasi untuk mempertahankan sumber daya manusia sebagai komponen utama dan merupakan komponen biaya yang paling penting. Disamping pertimbangan tersebut penghargaan juga merupakan salah satu aspek yang berarti bagi pegawai, karena bagi individu atau pegawai besarnya
9) Kondisi perekonomian nasional

10) Apabila kondisi perekonomian nasional sedang maju maka tingkat penghargaan akan semakin meningkat, karena akan mendekati kondisi full employment.

penghargaan mencerminkan ukuran nilai karya mereka diantara para pegawai itu sendiri, keluarga dan masyarakat.

Dalam menjatuhkan hukuman disiplin, maka pejabat yang berwenang menghukum sebelumnya wajib memeriksa terhadap tersangka yang telah melanggar ketentuan, tujuannya ialah untuk mengetahui apakah yang bersangkutan benar telah melakukan pelanggaran serta untuk mengetahui faktor-faktor yang mendorong dilakukan pelanggaran tersebut (Sudibyo Triatmodjo, 1983:166).

Hukuman yang dapat dijatuhkan sebagai sanksi terhadap pelanggaran disiplin PNS ialah teguran lisan, teguran tertulis, pernyataan tidak puas, penundaan kenaikan gaji berkala, penundaan kenaikan pangkat, penurunan pangkat, pemindahan 
sebagai hukuman, pembebasan tugas, dan pemberhentian.

Selain dari pada keharusan, larangan, sanksi dalam peraturan disiplin PNS juga diatur tentang pejabat yang berwenang menjatuhkan hukuman disiplin dan tata cara mengajukan keberatan/pembelaan, apabila seorang PNS tidak menerima disiplin yang dijatuhkan kepadanya.

\subsubsection{Pelanggaran Disiplin}

Secara ucapan, tulisan atau perbuatan pegawai negeri sipil yang melanggar ketentuan peraturan disiplin (kewajiban dan larangan) adalah pelanggaran disiplin.

1) Ucapan adalah setiap kata-kata yang diucapkan dihadapan atau dapat didengar oleh orang lain, seperti dalam rapat, ceramah, diskusi, melalui telepon, radio, televisi, rekaman atau alat komunikasi lainnya.

2) Tulisan adalah pernyataan pikiran dan atau perasaan secara tertulis baik dalam bentuk tulisan maupun dalam bentuk gambar, karikatur, coretan dari lain-lainnya yang serupa dengan itu. Perubahan adalah setiap tingkah laku, sikap atau tindakan dengan tidak mengurangi ketentuan dalam peraturan perundang- undangan pidana, PNS yang melakukan pelanggaran disiplin dijatuhi hukuman disiplin oleh pejabat yang berwenang menghukum.

\subsubsection{Motivasi}

Menurut Wibowo (2007) menjelaskan kinerja ditentukan oleh tujuan hendak dicapai dan untuk melakukannya diperlukan motivasi. Tanpa adanya motivasi untuk mencapai tujuan kinerja tidak akan berjalan. Motivasi akan tinggi sampai tingkat penghargaan yang diterima seseorang individu atas kinerja yang tinggi memenuhi kebutuhankebutuhan dominan yang konsisten dengan tujuan individual (Robbins 2003).

Menurut George R. dan Leslie $\boldsymbol{W}$. (dalam bukunya Matutina. dkk, 1993) mengatakan bahwa motivasi adalah "......getting a person to exert a high degree of effort ...." yang artinya motivasi membuat seseorang bekerja lebih berprestasi. Sedang Ravianto (1986) dalam bukunya ada beberapa faktor yang dapat mempengaruhi motivasi kinerja, yaitu atasan, rekan, sarana fisik, kebijaksanaan dan peraturan, imbalan 
jasa uang, jenis pekerjaan.

Dengan demikian dapat
dikatakan bahwa motivasi pada
dasarnya adalah kondisi mental yang
mendorong dilakukannya suatu
tindakan (action atau activities) dan
memberikan kekuatan yang mengarah
kepada pencapaian kebutuhan, memberi kepuasan ataupun mengurangi ketidak seimbangan. Ada definisi yang menyatakan bahwa motivasi berhubungan dengan :

1) Pengaruh perilaku.

2) Kekuatan reaksi (maksudnya upaya kerja), setelah seseorang karyawan telah memutuskan arah tindakan-tindakan.

3) Persistensi perilaku, atau berapa lama orang yang bersangkutan melanjutkan pelaksanaan perilaku dengan cara tertentu. (Campell , 1970).

Motivasi atau dorongan kepada karyawan untuk bersedia bekerja bersama demi tercapainya tujuan bersama ini terdapat dua macam, yaitu:

1) Motivasi finansial, yaitu dorongan yang dilakukan dengan memberikan imbalan finansial kepada karyawan. Imbalan tersebut sering disebut insentif.

2) Motivasi nonfinansial, yaitu dorongan yang diwujudkan tidak dalam bentuk finansial/ uang, akan tetapi berupa hal-hal seperti pujian, penghargaan, pendekatan manusia dan lain sebagainya (Gitosudarmo dan Mulyono, 1999)

Teori motivasi dikelompokkan menjadi dua kelompok, yaitu teori kepuasan (content theory) dan teori proses (process theory). Teori ini dikenal dengan nama konsep Higiene, yang mana cakupannya adalah:

1). Isi Pekerjaan

Hal ini berkaitan langsung dengan sifat-sifat dari suatu pekerjaan yang dimiliki oleh tenaga kerja yang isinya meliputi :Prestasi, upaya dari pekerjaan atau karyawan sebagai aset jangka panjang dalam menghasilkan sesuatu yang positif di dalam pekerjaannya, pengakuan, pekerjaan itu sendiri, tanggung jawab, pengembangan potensi individu.

\section{2). Faktor Higienis.}

Suatu motivasi yang dapat diwujudkan seperti halnya: gaji dan upah, kondisi kerja, kebijakan dan administrasi perusahaan, hubungan 
antara pribadi, kualitas supervisi. Pada teori tersebut bahwa perencanaan pekerjaan bagi karyawan haruslah menunjukkan keseimbangan antara dua faktor.

\subsection{Riview Penelitian Terdahulu}

Penelitian tentang Anggaran Berbasis Kinerja telah banyak dilakukan dan apabila dibandingkan dengan penelitian ini akan mempunyai beberapa kesamaan antara lain permasalahan yang akan dibahas mengenai penyususnan APBD, tata pemerintahan yang baik dan penganggaran berbasis kinerja.

Asmoko ( 2006 ) di Kabupaten Sragen Jawa Tengah melakukan penelitian tentang Pengaruh Penganggaran Berbasis Kinerja Terhadap Efektivitas Pengendalian.

Hasil penelitian Hindri Asmoko Menunjukkan bahwa penganggaran berbasis kinerja berpengaruh positif secara signifikan terhadap efektivitas pengendalian keuangan dan pengendalian kinerja.

Handayani (2009) melakukan penelitian di Provinsi Semarang tentang Pengaruh Reformasi Penyusunan Anggaran Terhadap Kualitas APBD. Hasilnya menunjukkan ada dampak akuntabilitas publik, partisipasi publik, transparansi publik dan pendekatan APBD terhadap kualitas APBD.

Selanjutnya Erawati

(2009) meneliti tentang Pengaruh Partisipasi Penyusunan Anggaran Berbasis Kinerja (ABK) Terahadap Kinerja Kepala Satuan Kerja Perangkat Daerah (SKPD) Pemerintah Daerah Dengan Komitmen Organisasi Dan Gaya Kepemimpinan Sebagai Variabel Moderating. Yang hasilnya menunjukkan Bahwa Partisipasi Penyusunan berbasis kinerja mempunyai pengaruh yang signifikan terhadap kinerja kepala SKPD, Komitmen organisasi tidak mempunyai pengaruh yang signifikan terhadap hubungan antara partisipasi penyusunan ABK dengan kepala SKPD, Gaya Kepemimpinan mempunyai pengaruh yang signifikan terhadap hubungan antara partisipasi penyusunan $\mathrm{ABK}$ dengan kepala SKPD Pemerintah Daerah.

Widyantoro ( 2009 ) di Semarang melakukan penelitian tentang Implementasi Performance Based Budgeting Sebuah Kajian Fenomologis. Hasil Penelitian menunjukkan bahwa secara umum Penganggaran Berbasis Kinerja yang ideal belum tercapai meskipun para 
pegawai dan pimpinan memahami makna penganggaran berbasis kinerja.

Sembiring (2009) di Kabupaten Karo meneliti tentang Faktor-faktor yang mempengaruhi penyusunan APBD berbasis kinerja (Studi Empiris di Pemerintah Kabupaten Karo). Hasilnya menunjukkan bahwa Secara simultan Komitmen dari seluruh komponen organisasi,Penyempurnaan Sistim Administrasi, Sumber Daya Yang Cukup, Penghargaan, Sanksi berpengaruh signifikan terhadap APBD berbasis kinerja.
Sutrisno (2010) di Rembang melakukan penelitian tentang Pengaruh Partisispasi, Motivasi dan pelimpahan wewenang dalam penyusunan anggaran terhadap kinerja manajerial. Hasil peneletian menyebutkan bahwa Partisipasi dalam penyusunan anggaran dan pelimpahan wewenang berpengaruh signifikan terhadap kinerja manajerial dengan hasil sedang sedangkan variabel motivasi tidak berpengaruh signifikan terhadap manajerial.

\subsection{Kerangka Pemikiran}

Berdasarkan landasan teori dan masalah penelitian maka penulis mengembangkan kerangka penelitian sebagai berikut:

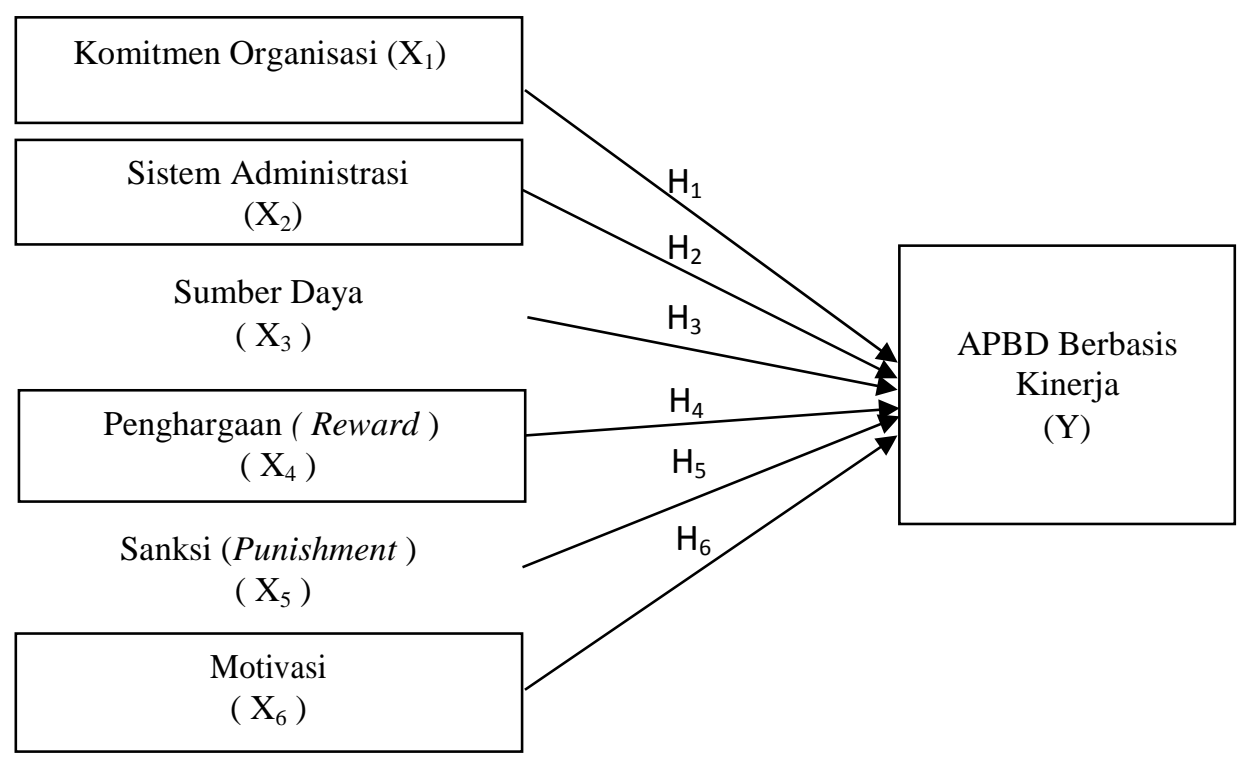

Gambar 1 Kerangka Pemikiran 
kerangka konsep yang telah dikemukakan maka Hipotesis yang diinginkan dalam penelitian ini adalah sebagai berikut :

1) Pengaruh komitmen organisasi dalam penyusunan APBD berbasis kinerja.

Komitmen

organisasi

merupakan kesepakatan antara kepala satuan kerja perangkat daerah beserta seluruh komponen organisasi dalam melaksanakan tugas pokok dan fungsi organisasinya untuk keberhasilan melaksanakan visi,misi,tujuan, sasaran sesuai dengan Renstra SKPD. Mowday,Poster, dan Steers (1982) mendifinisikan Komitmen

Organisasi sebagai: the relative strength of an individua's identification with and involvement in particuler organization. Definisi ini menunjukkan bahwa komitmen organisasi memiliki arti lebih dari sekedar loyalitas yang pasif, tetapi melibatkan hubungan aktif dan keinginan karyawan untuk memberikan kontribusi yang berarti pada organisasinya.

Pengaruh komitmen organisasi terhadap penyusunan APBD berbasis kinerja, penelitian yang dilakukan oleh Sembiring 2009 dengan hasil bahwa komitmen organisasi tidak ada pengaruh terhadap penyusunan APBD berbasis kinerja. Oleh karena itu penelitian ini menguji kembali dengan responden lebih banyak yaitu sebanyak 104 sedangkan penelitian sebelumnya menggunakan responden $70 . \quad$ Berdasarkan gambaran diatas maka dapat dirumuskan hipotesis sebagai berikut:

$\mathrm{H}_{1}$ : Komitmen organisasi berpengaruh positif terhadap penyusunan APBD berbasis kinerja di Pemerintah Daerah Provinsi Bengkulu.

2) Pengaruh sistim administrasi dalam penyusunan APBD berbasis kinerja.

Sistem administrasi mempunyai tujuan untuk tercapainya efisiensi dan efektivitas dalam bidang organisasi baik dalam metode dan prosedur dan personalia, sehingga mampu menyusun program pembangunan dan benar- benar melaksanakan program pembangunan tersebut. Menurut Bintaro 
penyempurnaan administrasi berarti perubahan langsung keseluruh administrasi untuk mencapai tujuan masyarakat yang menyeluruh yaitu modernisasi. Penyempurnaan administrasi merupakan suatu usaha yang sengaja dilakukan untuk menambah struktur dan prosedur birokrasi pemerintah, sikap dan tindakan aparat birokrasi atau kedua-duanya supaya dapat meningkatkan efektifitas organisasi dan mencapai tujuan pembangunan nasional. Kesimpulannya penyempurnaan administrasi merupakan penyajian instrumen pengukuran anggaran berbasis kinerja secara terus menerus. Berdasarkan gambaran diatas maka dapat dirumuskan hipotesis sebagai berikut:

$\begin{array}{rlr}\mathrm{H}_{2}: & \text { Sistem administrasi } \\ & \text { berpengaruh positif } \\ & \text { terhadap penyusunan } \\ & \text { APBD berbasis kinerja di } \\ & \text { Pemerintah Daerah } \\ & \text { Provinsi Bengkulu. }\end{array}$

3) Pengaruh sumber daya dalam penyusunan APBD berbasis kinerja.

Manajemen sumber daya
manusia diperlukan untuk

meningkatkan efektivitas

sumber daya manusia dalam organisasi. Tujuannya adalah memberikan kepada organisasi satuan kerja yang efektif. Produktivitas karyawan menjadi pusat perhatian dalam upaya untuk meningkatkan kinerja yang mempengaruhi tingkat efisiensi dan efektifitas organisasi. Analisis yang lebih mengkonsentrasikan pada kinerja akan lebih memberikan penekanan pada 3 faktor utama Ravianto (1995) menyatakan motivasi dari karyawan, kemampuan dari karyawan serta dukungan organisasional. Sumber daya yang cukup yaitu tersedianya upaya peningkatan implementasi anggaran berbasis kinerja berupa adanya upaya penyediaan sarana dan prasarana peningkatan kualitas implementasi anggaran berbasis kinerja.

Berdasarkan gambaran diatas maka dapat dirumuskan hipotesis sebagai berikut:

$\mathrm{H}_{3}$ : Sumber Daya berpengaruh positif terhadap penyusunan APBD berbasis kinerja di Pemerintah Daerah Provinsi Bengkulu. 
4) Pengaruh penghargaan dalam penyusunan APBD berbasis kinerja.

Program penghargaan penting bagi organisasi karena mencerminkan upaya organisasi untuk mempertahankan sumberdaya manusia sebagai komponen utama dan merupakan komponen biaya yang paling penting. Disamping pertimbangan tersebut penghargaan juga merupakan salah satu aspek yang berarti bagi pegawai, karena bagi individu atau pegawai besarnya penghargaan mencerminkan ukuran nilai karya mereka diantara para pegawai itu sendiri, keluarga dan masyarakat (Sulistiyani dan Rosidah,2003). Penghargaan bentuk metode dalam memotivasi seseorang untuk melakukan kebaikan dan meningkatkan prestasinya, dalam hal implementasi anggaran berbasis kinerja ini perlu dijaga konsistensi perencanaan dengan penganggaran. Berdasarkan gambaran diatas maka dapat dirumuskan hipotesis sebagai berikut:

$\mathrm{H}_{4}$ : Penghargaan berpengaruh positif terhadap penyusunan APBD berbasis kinerja di Pemerintah Daerah Provinsi Bengkulu.
5) Pengaruh sanksi dalam penyusunan APBD berbasis kinerja.

Pelanggaran kerja adalah setiap ucapan, tulisan, perbuatan seseorang pegawai yang melanggar peraturan disiplin yang telah diatur oleh pimpinan organisasi. Sedangkan Sanksi pelanggaran kerja adalah hukuman disiplin yang dijatuhkan pimpinan organisasi kepada pegawai yang melanggar peraturan disiplin yang telah diatur oleh organisasi. Sanksi (punishment) merupakan bentuk metode dalam memotivasi seseorang untuk melakukan kebaikan dan meningkatkan prestasinya, dalam hal implementasi anggaran berbasis kinerja ini perlu dijaga konsistensi perencanaan dengan penganggaran dan pemberian punishment yang jelas bagi satuan kerja perangkat daerah. Berdasarkan gambaran diatas maka dapat dirumuskan hipotesis sebagai berikut:

$$
\begin{aligned}
\mathrm{H}_{5} & \text { : } \\
& \text { Sanksi berpengaruh positif } \\
& \text { berbasis penyusunan APBD } \\
& \text { Pemerintah Daerah Provinsi } \\
& \text { Bengkulu. }
\end{aligned}
$$

6) Pengaruh motivasi dalam 
penyusunan APBD berbasis kinerja.

Setiap perusahaan atau organisasi pemerintah bukan saja mengharapkan bawahannya yang mampu, cakap, trampil tetapi yang penting mau bekerja giat dan berkeinginan untuk mencapai hasil kerja yang optimal. Kemampuan kecakapan dan ketrampilan karyawan atau pegawai tidak ada artinya bagi instansi pemerintah daerah jika merka tidak bekerja keras dengan mempergunakan kemampuan kecakapan dan

\section{METODOLOGI PENELITIAN}

\subsection{Objek dan Subjek Penelitian}

Penelitian ini menggunakan enam variabel bebas (independen) dan satu variabel terikat (dependen). Operasionalisasi variabel dilakukan dengan melalui intrumentasi yang berbentuk kuesioner. Pertanyaan diukur dalam skala likert lima poin.

a. Analisis Regresi Berganda

Analisis ini digunakan karena penelitian ini menganalisis pengaruh antara satu variabel dependen dengan beberapa variabel independen. Sebagai variabel dependen adalah APBD berbasis kinerja , variabel ketrampilan yang dimiliki. Motivasi akan tinggi sampai tingkat penghargaan yang diterima seseorang individu atas kinerja yang tinggi memenuhi kebutuhankebutuhan dominan yang konsisten dengan tujuan individual (Robbins 2003). Berdasarkan gambaran diatas maka dapat dirumuskan hipotesis sebagai berikut: .

$\mathrm{H}_{6}$ : Motivasi berpengaruh positif terhadap penyusunan APBD berbasis kinerja di Pemerintah Daerah Provinsi Bengkulu.

independennya komitmen organisasi, sistim administrasi, sumber daya, penghargaan, sanksi dan motivasi.

$\mathrm{ABK}=\beta_{0}+\beta_{1} \mathrm{KOM}+\beta_{2} \mathrm{SA}+\beta_{3} \mathrm{SD}+$ $\beta_{4} \mathrm{PHG}+\beta_{5} \mathrm{SNK}+\beta_{6} \mathrm{MTV}+\mathrm{e}$

Keterangan:

ABK $=$ APBD berbasis kinerja $\begin{array}{llllllll}\beta_{0} & \beta_{1} & \beta_{2} & \beta_{3} & \beta_{4} & \beta_{5} & \beta_{6}\end{array}=$ Konstanta digunakan untuk menyatakan apakah terjadi heteroskedastisitas atau tidak diantara data-data pengamatan dapat dilihat nilai koefisien signifikansinya (dalam hal ini ditetapkan $\alpha=$ Koefisiensi regresi 0,005). Apabila koefisien signifikansi lebih besar dari $\alpha$ $(0,005)$, maka dapat dinyatakan tidak 
terjadi

$\begin{array}{ll}\text { KOM } & =\text { Komitmen organisasi } \\ \text { SA } & =\text { Sistem administrasi } \\ \text { SD } & =\text { Sumber daya } \\ \text { PHG } & =\text { Penghargaan ( reward } \\ & \text { ) yang jelas } \\ \text { SNK } & =\text { Sanksi (punishment) } \\ \text { yang tegas } & \\ \text { MTV } & =\text { Motivasi } \\ \text { e } & =\text { Error term }\end{array}$

b. Uji t (t-test)

Uji ini dilakukan untuk mengetahui signifikansi dari setiap variable independent terhadap variable dependen. Dengan $\alpha=0,005$, hipotesis yang diuji akan diterima.

c. Uji Koefisien Determinan $\left(\mathrm{R}^{2}\right)$

Uji ini digunakan untuk menunjukkan seberapa besar prosentase variasi dalam variabel diperlukan yang dapat dijelaskan oleh variasi dalam variabel independen. Nilai $\mathrm{R}$ terletak antara nilai 0 dan 1 . Jika $\mathrm{R}^{2}$ semakin mendekati satu, maka semakin besar variasi dalam variabel independen. Hal ini berarti semakin tepat garis regresi tersebut mewakili hasil-hasil observasi yang sebenarnya (Wheel Wright dan Makridakis,1995).

\subsection{Hasil Pengujian Asumsi Klasik}

a. Heteroskedastisitas

Pengujian heteroskedastisitas menggunakan bantuan SPSS dilakukan dua tahap, yaitu menghitung nilai residual absolutnya terlebih dahulu baru menghitung korelasi antara nilai variabel dengan nilai residual. Kriteria yang heteroskedastisitas diantara data pengamatan tersebut.

b. Multikolinieritas

Pengujian ini dilakukan untuk mengetahui apakah ditemukan adanya korelasi antar variabel independen. Jika terjadi korelasi, maka terdapat masalah multikolinieritas. Model regresi yang baik seharusnya tidak terjadi korelasi antara variabel independennya. Multikolinieritas yang berbahaya terjadi apabila nilai dari variance inflation factor (VIF) lebih besar dari 10 (Gujarati, 1993).

c. Autokorelasi

Pengujian ini dilakukan untuk mengetahui apakah regresi hasil pengolahan ada korelasi antara residual pada satu pengamatan dengan pengamatan yang lain dalam satu variabel. Konsekuensi dari autokorelasi adalah biasnya varian dengan nilai yang lebih kecil dari nilai 
yang sebenarnya, sehingga nilai $\mathrm{R}^{2}$ dan F cenderung overestimated. Cara untuk mendeteksi autokorelasi adalah dengan menggunakan pengujian Durbin Watson (DW) dengan ketentuan : nilai DW antara 1,65 sampai 2,35 dapat disimpulkan tidak ada Autokorelasi Makridakis dkk, 1995).

\subsection{Hasil Pengujian Hipotesis dan Pembahasan}

a. Analisis Regresi Berganda

Hasil analisis regresi berganda untuk mengetahui pengaruh variabel independent komitmen organisasi, sistem administrasi, sumber daya, penghargaan, sanksi dan motivasi, Tingkat Kesulitan Tujuan Anggaran terhadap variabel dependen APBD berbasis kinerja, digunakan menggunakan program SPSS.

\section{Coefficients $^{\mathrm{a}}$}

\begin{tabular}{|c|c|c|c|c|c|c|}
\hline \multirow{2}{*}{\multicolumn{2}{|c|}{ Model }} & \multicolumn{2}{|c|}{$\begin{array}{l}\text { Unstandardized } \\
\text { Coefficients }\end{array}$} & \multirow{2}{*}{$\begin{array}{c}\text { Standardized } \\
\text { Coefficients } \\
\text { Beta }\end{array}$} & \multirow[t]{2}{*}{$\mathrm{t}$} & \multirow[t]{2}{*}{ Sig. } \\
\hline & & B & Std. Error & & & \\
\hline \multirow[t]{9}{*}{1} & (Constant) & 2.165 & .823 & & 4.188 & .000 \\
\hline & Komitmen (X1) & 169 & .080 & .214 & 2.113 & .037 \\
\hline & Sistem Administrasi & .213 & .095 & .304 & 2.186 & .019 \\
\hline & $(\mathrm{X} 2)$ & & & & & \\
\hline & Sumber Daya yang & 225 & .014 & .408 & 2.197 & .016 \\
\hline & Cukup (X3) & & & & & \\
\hline & $\begin{array}{l}\text { Penghargaan_Reward } \\
\text { (X4) }\end{array}$ & .206 & .107 & 270 & 2.919 & .028 \\
\hline & Sanksi (X5) & .567 & .103 & .484 & 5.512 & .000 \\
\hline & Motivasi (X6) & .110 & .123 & .131 & 2.030 & .042 \\
\hline
\end{tabular}

a. Dependent Variable: APBD Berbasis Kinerja (Y)

Sumber: data primer diolah 2016 
Persamaan Regresi yang telah dirumuskan kemudian dengan bantuan SPSS dilakukan pengolahan data sehingga didapat persamaan akhir sebagai berikut:

$Y=2,165+0,169 \mathrm{KOM}+0,213 \mathrm{SA}+$ 0,225 SD +0,206 PHG + 0,567 SNK + 0,110 MTV

Nilai besaran koefisien regresi $\beta_{1}$ sebesar 0,169 pada penelitian ini dapat diartikan bahwa variabel komitmen organisasi $\left(\mathrm{X}_{1}\right)$ berpengaruh positif terhadap APBD berbasis Kinerja (Y). Hal ini menunjukkan bahwa ketika komitmen organisasi mengalami peningkatan sebesar satu satuan maka APBD berbasis kinerja juga akan mengalami peningkatan sebesar 0,169 satuan.

Nilai besaran koefisien regresi $\beta_{2}$ sebesar 0,213 pada penelitian ini dapat diartikan bahwa variabel sistim administrasi $\left(\mathrm{X}_{2}\right)$ berpengaruh positif terhadap APBD berbasis Kinerja (Y). Hal ini menunjukkan bahwa ketika sistim administrasi mengalami peningkatan sebesar satu satuan maka APBD berbasis kinerja juga akan mengalami peningkatan sebesar 0,213 satuan. sebesar 0,225 pada penelitian ini dapat diartikan bahwa variabel sumber daya $\left(\mathrm{X}_{3}\right)$ berpengaruh positif terhadap APBD berbasis Kinerja (Y). Hal ini menunjukkan bahwa ketika sumber daya mengalami peningkatan sebesar satu satuan maka APBD berbasis kinerja juga akan mengalami peningkatan sebesar 0,225 satuan.

Nilai besaran koefisien regresi $\beta_{4}$ sebesar 0,206 pada penelitian ini dapat diartikan bahwa variabel penghargaan $\left(\mathrm{X}_{4}\right)$ berpengaruh positif terhadap APBD berbasis Kinerja (Y). Hal ini menunjukkan bahwa ketika penghargaan mengalami peningkatan sebesar satu satuan maka APBD berbasis kinerja juga akan mengalami peningkatan sebesar 0,206 satuan.

Nilai besaran koefisien regresi $\beta_{5}$ sebesar 0,567 pada penelitian ini dapat diartikan bahwa variabel sanksi $\left(\mathrm{X}_{5}\right)$ berpengaruh positif terhadap APBD berbasis Kinerja (Y). Hal ini menunjukkan bahwa ketika sanksi mengalami peningkatan sebesar satu satuan maka APBD berbasis kinerja juga akan mengalami peningkatan sebesar 0,567 satuan. Nilai besaran koefisien regresi $\beta_{6}$ sebesar 0,110 pada penelitian ini dapat diartikan bahwa variabel motivasi $\left(\mathrm{X}_{6}\right)$ berpengaruh 
positif terhadap APBD berbasis Kinerja

(Y). Hal ini menunjukkan bahwa ketika motivasi mengalami peningkatan sebesar satu satuan maka APBD berbasis kinerja juga akan mengalami peningkatan sebesar 0,110 satuan.

\section{b.Uji Koefisien Determinasi}

Berdasarkan tampilan output model summary pada tabel 4-11 besarnya adjusted $\mathrm{R}^{2}$ (koefisien determinasi yang telah disesuaikan) sebesar 0,474 . Sehingga dapat dikatakan bahwa 47,4 \% variasi variabel dependen yaitu penyusunan APBD berbasis kinerja (Y) pada model dapat diterangkan oleh variabel bebas yaitu komitmen organisasi $\left(\mathrm{Y}_{1}\right)$, sistim administrasi $\left(\mathrm{X}_{2}\right)$, sumber daya $\left(\mathrm{X}_{3}\right)$, Penghargaan $\left(\mathrm{X}_{4}\right)$, sanksi $\left(\mathrm{X}_{5}\right)$ motivasi $\left(\mathrm{X}_{6}\right)$ sedangkan sisanya 52,6 $\%$ dijelaskan oleh sebab lain diluar model yang tidak diteliti.

\section{c. Uji Simultan (uji F)}

Dari hasil pengujian terhadap simultan ANOVA atau $F$ test seperti yang ditampilkan pada tabel 4-12 dibawah ini diperoleh nilai $F_{\text {hitung }}$ sebesar 16,486 dengan probabilitas 0,000. Karena probabilitas jauh lebih kecil dari nilai signifikan 0,05 , maka model regresi dapat digunakan untuk memprediksi Penyusnan APBD berbasis kinerja atau dapat dikatakan bahwa komitmen organisasi, sistem administrasi, sumberdaya, penghargaan, sanksi, dan motivasi secara simultan berpengaruh terhadap penyusunan APBD berbasis kinerja.

\section{d.Uji Parsial (uji t)}

Hasil Hipotesis pertama $\left(\mathrm{H}_{1}\right)$ yang menyebutkan bahwa Komitmen organisasi berpengaruh positif terhadap penyusunan APBD berbasis kinerja di Pemerintah Daerah Provinsi Bengkulu dikomfirmasi pada tabel 413 yang menunjukkan bahwa nilai koefisien regresi variabel Komitmen Organisasi $\left(\mathrm{X}_{1}\right)$ adalah 0.169 dan nilai $\mathrm{t}_{\text {hitung }} 2,113$, nilai koefisien regresi ini signifikan pada tingkat signifikansi 0,005 dengan $p$ value sebesar 0,037 .

Hasil ini dipertegas dengan hasil perhitungan nilai $t_{\text {hitung }}$ dan $t_{\text {tabel }}$. Nilai $t_{\text {abel }}$ pada taraf signifikansi $5 \%$ dan df (derajat kebebasan) n- k-1 = 97 adalah 1,985. Dengan demikian nilai $t_{\text {hitung }}$ $2,113>\mathrm{t}_{\text {tabel }} 1,985$. Hasil pengujian ini menginterprestasikan bahwa variabel Komitmen Organisasi berpengaruh signifikan dan positif terhadap penyusunan APBD berbasis kinerja pada taraf signifikan $5 \%$ atau dengan kata lain $\mathrm{H}_{1}$ diterima.

Hasil pengujian hipotesis kedua 
$\left(\mathrm{H}_{2}\right)$ yang menyebutkan bahwa Sistem administrasi berpengaruh positif terhadap penyusunan APBD berbasis kinerja di Pemerintah Daerah Provinsi Bengkulu dikomfirmasi pada tabel 4-11 yang menunjukkan bahwa nilai koefisien regresi variabel sistim administrasi $\left(\mathrm{X}_{2}\right)$ adalah 0.213 dan nilai $\mathrm{t}_{\text {hitung }} 2,186$, nilai koefisien regresi ini signifikan pada tingkat signifikansi 0,005 dengan $p$ value sebesar 0,019 .

Hasil ini dipertegas dengan hasil perhitungan nilai $t_{\text {hitung }}$ dan $t_{\text {tabel }}$. Nilai $t_{\text {abel }}$ pada taraf signifikansi $5 \%$ dan df (derajat kebebasan) n- k-1 = 97 adalah 1,985. Dengan demikian nilai $t_{\text {hitung }}$ $2,186>t_{\text {tabel }} 1,985$. Hasil pengujian ini menginterprestasikan bahwa variabel sistem administrasi berpengaruh signifikan dan positif terhadap penyusunan APBD berbasis kinerja pada taraf signifikan $5 \%$ atau dengan kata lain $\mathrm{H}_{2}$ diterima .

Hasil pengujian hipotesis kedua $\left(\mathrm{H}_{3}\right)$ yang menyebutkan bahwa sumber daya berpengaruh positif terhadap penyusunan APBD berbasis kinerja di Pemerintah Daerah Provinsi Bengkulu dikomfirmasi pada tabel 4-12 yang menunjukkan bahwa nilai koefisien regresi variabel sumber daya (X3) adalah 0.225 dan nilai $t_{\text {hitung }} 2,197$, nilai koefisien regresi ini signifikan pada tingkat signifikansi 0,005 dengan $p$ value sebesar 0,016.

Hasil ini dipertegas dengan hasil perhitungan nilai $t_{\text {hitung }}$ dan $t_{\text {tabel }}$. Nilai $t_{\text {abel }}$ pada taraf signifikansi $5 \%$ dan df (derajat kebebasan) n- k-1 = 97 adalah 1,985. Dengan demikian nilai $t_{\text {hitung }}$ $2,197>t_{\text {tabel }} 1,985$. Hasil pengujian ini menginterprestasikan bahwa variabel sumber daya berpengaruh signifikan dan positif terhadap penyusunan APBD berbasis kinerja pada taraf signifikan 5 $\%$ atau dengan kata lain $\mathrm{H}_{3}$ diterima .

Hasil pengujian hipotesis kedua $\left(\mathrm{H}_{4}\right)$ yang menyebutkan bahwa penghargaan berpengaruh positif terhadap penyusunan APBD berbasis kinerja di Pemerintah Daerah Provinsi Bengkulu dikomfirmasi pada tabel 4-13 yang menunjukkan bahwa nilai koefisien regresi variabel penghargaan $\left(\mathrm{X}_{4}\right)$ adalah 0.206 dan nilai $\mathrm{t}_{\text {hitung }} 2,919$ nilai koefisien regresi ini signifikan pada tingkat signifikansi 0,005 dengan $p$ value sebesar 0,028 .

Hasil ini dipertegas dengan hasil perhitungan nilai $t_{\text {hitung }}$ dan $t_{\text {tabel }}$. Nilai $t_{\text {abel }}$ pada taraf signifikansi $5 \%$ dan df (derajat kebebasan) n- k-1 = 97 adalah 1,985. Dengan demikian nilai $t_{h i t u n g}$ $2,919>\mathrm{t}_{\text {tabel }} 1,985$. Hasil pengujian ini 
menginterprestasikan bahwa variabel penghargaan berpengaruh signifikan dan positif terhadap penyusunan APBD berbasis kinerja pada taraf signifikan 5 $\%$ atau dengan kata lain $\mathrm{H}_{4}$ diterima .

Hasil pengujian hipotesis kedua $\left(\mathrm{H}_{5}\right)$ yang menyebutkan bahwa sanksi berpengaruh positif terhadap penyusunan APBD berbasis kinerja di Pemerintah Daerah Provinsi Bengkulu dikomfirmasi pada tabel 4- 13 yang menunjukkan bahwa nilai koefisien regresi variabel sanksi $\left(\mathrm{X}_{5}\right)$ adalah 0.567 dan nilai $t_{\text {hitung }} 5,512$ nilai koefisien regresi ini signifikan pada tingkat signifikansi 0,005 dengan $p$ value sebesar 0,000 .

Hasil ini dipertegas dengan hasil perhitungan nilai $t_{\text {hitung }}$ dan $t_{\text {tabel }}$. Nilai $\mathrm{t}_{\text {abel }}$ pada taraf signifikansi $5 \%$ dan df (derajat kebebasan) n- k-1 = 97 adalah 1,985. Dengan demikian nilai $t_{h i t u n g}$ $5,512>t_{\text {tabel }} 1,985$. Hasil pengujian ini menginterprestasikan bahwa variabel sanksi berpengaruh signifikan dan positif terhadap penyusunan APBD berbasis kinerja pada taraf signifikan 5 $\%$ atau dengan kata lain $\mathrm{H}_{5}$ diterima .

Hasil pengujian hipotesis kedua $\left(\mathrm{H}_{6}\right)$ yang menyebutkan bahwa motivasi berpengaruh positif terhadap penyusunan APBD berbasis kinerja di
Pemerintah Daerah Provinsi Bengkulu dikomfirmasi pada tabel 4- 13 yang menunjukkan bahwa nilai koefisien regresi variabel motivasi $\left(\mathrm{X}_{6}\right)$ adalah 0.110 dan nilai $t_{\text {hitung }} 2,030$, nilai koefisien regresi ini signifikan pada tingkat signifikansi 0,005 dengan $p$ value sebesar 0,042 .

Hasil ini dipertegas dengan hasil perhitungan nilai $t_{\text {hitung }}$ dan $t_{\text {tabel }}$. Nilai $\mathrm{t}_{\text {abel }}$ pada taraf signifikansi $5 \%$ dan df (derajat kebebasan) n- k-1 = 97 adalah 1,985. Dengan demikian nilai $t_{\text {hitung }}$ $2,030>t_{\text {tabel }} 1,985$. Hasil pengujian ini menginterprestasikan bahwa variabel motivasi berpengaruh signifikan dan positif terhadap penyusunan APBD berbasis kinerja pada taraf signifikan 5 $\%$ atau dengan kata lain $\mathrm{H}_{6}$ diterima.

\section{HASIL PENELITIAN DAN PEMBAHASAN}

\subsection{Pengaruh Penyusunan APBD}

\section{Berbasis Kinerja Terhadap \\ Komitmen Organisasi}

Hipotesis pertama $\left(\mathrm{H}_{1}\right)$ menyatakan bahwa komitmen organisasi berpengaruh positif terhadap penyusunan APBD berbasis kinerja Di Pemerintah Daerah Provinsi Bengkulu. Hasil pengujian statistik menunjukkan bahwa nilai koefisien 
regresi variabel komitmen organisasi $\left(\mathrm{X}_{1}\right)$ adalah 0.169 dan nilai $\mathrm{t}_{\text {hitung }}$ 2,113, nilai koefisien regresi ini signifikan pada tingkat signifikansi 0,005 dengan $p$ value sebesar 0,037. Hasil didukung oleh hasil perhitungan nilai $t_{\text {hitung }} 2,113>t_{\text {tabel }} 1,985$. Hal ini menunjukkan bahwa komitmen organisasi berpengaruh signifikan dan positif dalam penyusunan APBD berbasis kinerja, artinya bahwa pimpinan dan seluruh komponen SKPD telah melibatkan seluruh bawahannya dalam menjabarkan tugas pokok dan isntansinya.

Pengaruh positif menunjukkan bahwa pengaruh komitmen organisasi adalah searah dengan APBD berbasis kinerja atau dengan kata lain komitmen organisasi yang baik/tinggi akan berpengaruh terhadap APBD berbasis kinerja yang baik. Dari hasil tanggap respoden yang menyatakan bahwa Satuan kerja perangkat daerah /SKPD telah memiliki dokumen strategik ( renstra ) instansinya yang lebih operasional mempunyai rata-rata yang cukup tinggi yaitu sebesar 4,57\% demikian sebaliknya bila komitmen organisasi rendah maka APBD berbasis kinerja akan rendah. Pengaruh signifikan menunjukkan bahwa komitmen organisasi mempunyai peranan yang penting dalam meningkatkan APBD berbasis kinerja

\subsection{Pengaruh Penyusunan APBD} Berbasis Kinerja Terhadap Sistem Administrasi

Hipotesis pertama

menyatakan bahwa sistim administrasi berpengaruh positif terhadap penyusunan APBD berbasis kinerja di Pemerintah Daerah Provinsi Bengkulu. Hasil pengujian statistik menunjukkan bahwa nilai koefisien regresi variabel sistim administrasi $\left(\mathrm{X}_{2}\right)$ adalah 0.213 dan nilai $t_{\text {hitung }} 2,186$, nilai koefisien regresi ini signifikan pada tingkat signifikansi 0,005 dengan $p$ value sebesar 0,019. Hasil didukung oleh hasil perhitungan nilai $t_{\text {hitung }} 2,186>$ $\mathrm{t}_{\text {tabel }} 1,985$.

Pengaruh positif menunjukkan bahwa pengaruh sistim administrasi adalah searah dengan APBD berbasis kinerja atau dengan kata lain sistim administrasi yang baik/tinggi akan berpengaruh terhadap APBD berbasis kinerja yang baik.Jawaban responden yang menyatakan Dokumen Perencanaan Daerah ( Rencana Kerja Pemerintah Daerah), Rencana Strategik, Rencana Kinerja 
(Renstra/Renja SKPD ) tersebut, telah dilengkapi dengan ukuran pencapaian kinerja program dan kegiatan rata-rata $4,11 \%$ demikian sebaliknya bila sistim administrasi rendah maka APBD berbasis kinerja akan rendah. Pengaruh signifikan menunjukkan bahwa sistim administrasi mempunyai peranan yang penting dalam meningkatkan APBD berbasis kinerja.

\subsection{Pengaruh Penyusunan APBD}

Berbasis Kinerja Terhadap Sumber

Daya

$$
\text { Hipotesis pertama }\left(\mathrm{H}_{3}\right)
$$

menyatakan bahwa sumber daya berpengaruh positif terhadap penyusunan APBD berbasis kinerja di Pemerintah Daerah Provinsi Bengkulu.. Hasil pengujian statistik menunjukkan bahwa nilai koefisien regresi variabel sumber daya $\left(\mathrm{X}_{3}\right)$ adalah 0.225 dan nilai $t_{\text {hitung }} 2,197$, nilai koefisien regresi ini signifikan pada tingkat signifikansi 0,005 dengan $p$ value sebesar 0,016. Hasil didukung oleh hasil perhitungan nilai $t_{\text {hitung }} 2,197>t_{\text {tabel }} 1,985$. Pengaruh positif menunjukkan bahwa pengaruh sumberdaya adalah searah dengan APBD berbasis kinerja atau dengan kata lain sumberdaya yang baik/tinggi akan berpengaruh terhadap APBD berbasis kinerja yang baik. Jawaban responden yang menyatakan Sumber daya manusia pada SKPD sebaiknya setiap ada kesempatan diikutsertakan dalam pembelajaran/pelatihan tentang anggaran berbasis kinerja rata-rata $4,91 \%$ demikian sebaliknya bila sumberdaya rendah maka APBD berbasis kinerja akan rendah. Pengaruh signifikan menunjukkan bahwa sumberdaya mempunyai peranan yang penting dalam meningkatkan APBD berbasis kinerja.

\subsection{Pengaruh Penyusunan APBD}

\section{Berbasis Kinerja Terhadap \\ Penghargaan}

$$
\text { Hipotesis pertama }
$$

menyatakan bahwa penghargaan berpengaruh positif terhadap penyusunan APBD berbasis kinerja di Pemerintah Daerah Provinsi Bengkulu.. Hasil pengujian statistik menunjukkan bahwa nilai koefisien regresi variabel penghargaan $\left(\mathrm{X}_{4}\right)$ adalah 0.206 dan nilai $t_{\text {hitung }}$ 2,919, nilai koefisien regresi ini signifikan pada tingkat signifikansi 0,005 dengan $p$ value sebesar 0,028 . Hasil didukung oleh hasil perhitungan nilai $t_{\text {hitung }} 2,919$ $>t_{\text {tabel }} 1,985$.

Pengaruh positif menunjukkan bahwa pengaruh penghargaan adalah 
searah dengan APBD berbasis kinerja atau dengan kata lain penghargaan yang baik/tinggi akan berpengaruh terhadap APBD berbasis kinerja yang baik. Jawaba responden yang menyatakan Untuk menjamin efektifitas capaian kinerja tupoksi SKPD perlu adanya penghargaan/reward kepada seluruh komponen organisasi terutama kepada SKPD dan personil penyusunan anggaran. Dan Dengan adanya reward yang adil kepada satuan kerja perangkat daerah yang berhasil menjadi motivasi melaksanakan tujuan organisasinya,kedua jawaban responden rata-rata sama yaitu sebesar $4,73 \%$ demikian sebaliknya bila penghargaan rendah maka APBD berbasis kinerja akan rendah. Pengaruh signifikan menunjukkan bahwa penghargan mempunyai peranan yang penting dalam meningkatkan APBD berbasis kinerja.

\subsection{Pengaruh Penyusunan APBD}

\section{Berbasis Kinerja Terhadap Sanksi}

$\begin{array}{lcr}\text { Hipotesis } & \text { pertama } & \left(\mathrm{H}_{5}\right) \\ \text { menyatakan } & \text { bahwa } & \text { sanksi } \\ \text { berpengaruh } & \text { positif } & \text { terhadap }\end{array}$
penyusunan APBD berbasis kinerja di Pemerintah Daerah Provinsi Bengkulu Hasil pengujian statistik menunjukkan bahwa nilai koefisien regresi variabel sanksi $\left(\mathrm{X}_{5}\right)$ adalah 0.567 dan nilai $t_{\text {hitung }} 5,512$, nilai koefisien regresi ini signifikan pada tingkat signifikansi 0,005 dengan $p$ value sebesar 0,000. Hasil didukung oleh hasil perhitungan nilai $t_{\text {hitung }} 5,512$ $>\mathrm{t}_{\text {tabel }} 1,985$.

Pengaruh positif menunjukkan bahwa pengaruh sanksi adalah searah dengan APBD berbasis kinerja atau dengan kata lain sanksi yang baik/tinggi akan berpengaruh terhadap APBD berbasis kinerja yang baik. Jawaban responden dari pernyataan Pimpinan SKPD selaku bertanggungjawab atas keberhasilan tujuan organisasinya, agar orang yang paling bertanggungjawab memberi sanksi kepada bawahannya rata-rata $4,86 \%$, demikian sebaliknya bila sanksi rendah maka APBD berbasis kinerja akan rendah. Pengaruh signifikan menunjukkan bahwa sanksi mempunyai peranan yang penting dalam meningkatkan APBD berbasis kinerja.

\subsection{Pengaruh Penyusunan APBD}

\section{Berbasis Kinerja Terhadap Motivasi}

Hipotesis pertama $\left(\mathrm{H}_{6}\right)$ menyatakan bahwa motivasi berpengaruh positif terhadap 
penyusunan APBD berbasis kinerja di Pemerintah Daerah Provinsi Bengkulu. Hasil pengujian statistik menunjukkan bahwa nilai koefisien regresi variabel motivasi $\left(\mathrm{X}_{6}\right)$ adalah

0.110 dan nilai $t_{\text {hitung }} 2,030$, nilai koefisien regresi ini signifikan pada tingkat signifikansi 0,005 dengan $p$ value sebesar 0,042. Hasil didukung oleh hasil perhitungan nilai $t_{\text {hitung }} 2,030$ $>t_{\text {tabel }} 1,985$.

Pengaruh positif menunjukkan bahwa pengaruh motivasi adalah searah dengan APBD berbasis kinerja atau dengan kata lain motivasi yang baik/tinggi akan berpengaruh terhadap APBD berbasis kinerja yang baik. Jawaban responden yang menyatakan Pemberian penghargaan bagi SKPD yang berprestasi akan memberikan motivasi kerja rata-rata 5,41 \% demikian sebaliknya bila motivasi rendah maka APBD berbasis kinerja akan rendah. Pengaruh signifikan menunjukkan bahwa motivasi mempunyai peranan yang penting dalam meningkatkan APBD berbasis kinerja.

\section{SIMPULAN DAN SARAN}

\subsection{Simpulan}

Berdasarkan pembahasan hasil penelitian maka ditarik kesimpulan sebagai berikut:

1. Ada pengaruh positif antara variabel komitmen organisasi, sistem administrasi , sumberdaya , penghargaan, sanksi, dan motivasi terhadap penyusunan APBD berbasis kinerja. Hal ini dapat dilihat dari hasil perhitungan diperoleh $F_{\text {hitug }} 16,486$ pada taraf signifikan $5 \%\left(\mathrm{~F}_{\text {tabel }} 2,19\right)$. Dengan demikian $\mathrm{F}_{\text {hit }}>\mathrm{T}_{\text {tab }}$ sehingga dapat disimpulkan $\mathrm{Ha}$ diterima. Sedangkan sumbangan dari variabel yang diteliti sebesar 47,4 \% dan sisanya 52,6\% dipengaruhi oleh variabel lain yang tidak ada dalam penelitian ini.

2. Berdasarkan hasil parsial dapat disimpulkan bahwa: variabel komitmen organisasi sebesar 2,113, variabel Sistim Administrasi sebesar 2,186, variabel Sumberdaya sebesar $\quad 2,197, \quad$ variabel Penghargaan sebesar 2,919, variabel Sanksi sebesar 5,512, variabel motivasi sebesar 2,030. Jadi dapat disimpulkan bahwa variabel sanksi mempunyai sumbangan parsial terbesar dibandingkan dari variabel lain. 
Sanksi akan memberi pengaruh terbesar terhadap penyusunan APBD berbasis kinerja, karena sanksi merupakan hukuman bagi pengguna anggaran/SKPD yang tidak mematuhi ketentuan yang berlaku.

\subsection{Saran}

Saran penelitian selanjutnya untuk penyempurnaan penyusunan APBD berbasis kinerja disampaikan beberapa saran yaitu:

1. Kepada pemerintah Pemerintah Daerah Provinsi Bengkulu hendaknya memberi sanksi yang tegas kepada setiap SKPD dalam kaitannya penyusunan anggaran berbasis kinerja.

2. Kepada setiap SKPD selaku pengguna anggaran agar lebih meningkatan kinerja dalam kaitannya penyusunan anggaran berbasis kinerja, dengan mengikutsertakan pelatihanpelatihan materi penyusunan anggaran bagi karyawan untuk setiap SKPD.

\section{DAFTAR PUSTAKA}

Asmoko, Hindri 2006, Pengaruh
Penganggaran Berbasis Kinerja

Terhadap

Efektifitas

Pengendalian, Jurnal

Akuntansi Pemerintah, Vol2.

No2 Jogjakarta

BPKP 2010, Pedoman Penyusunan Anggaran Berbasis Kinerja (Revisi). Jakarta.

Benar Baik Sembiring, 2009, Faktorfaktor Yang Mempengaruhi Penyusunan APBD Berbasis Kinerja (Studi Empiris di Pemerintahan Kabupaten Karo), (Tesis)

Bestari Dwi Handayani,2009, Pengaruh Reformasi Penyusunan Anggaran Terhadap Kualitas APBD

Provinsi Semarang.

Bastian Indra, 2006, Sistem Perencanaan dan Penganggaran Pemerintahan Daerah di Indonesia, Salemba Empat, Jakarta.

Baswir, Revrison, 2002, Akuntansi Pemerintahan Indonesia, BPFE, Yogyakarta.

Basri dan Subsri, S, 2003, Keuangan Negara dan Desentralisasi Fiskal, LPEM FE-UI, Jakarta. 
Husein, Umar, 2008, Desain Penelitian

Due, Jhon F, 2000, Government Finance and Economic Analysis, Richard D Irwin Inc. New York.

Duwi, Priyanto, 2008, Mandiri Belajar SPSS Untuk Analisis Data dan Uji Statistik, Penerbit Mediakom, Yogyakarta.

Emory, CW \& DR Cooper, 1997, Business Research Methods. 4th Ed Irwin Illinois.

Gozali, Imam ， 2006, Aplikasi Multivariate dengan program SPSS, Edisi 3 Badan Penerbit Universitas Diponegoro, Semarang.

Gujarati, DN , 2004, BasicEconometric, $4^{\text {th }}$ ed, McGraw-Hill, New York.

Hertianti, Deddi, 2010, Akuntansi Sektor Publik,

Edisi ke-2 Penertbit Salemba Empat.

Hendra Cipta, 2011, Analisis Penerapan Penganggaran

Berbasis Kinerja (Performance Based Budgeting) Pada Pemerintah Daerah (studi eksploratif pada pemerintah kabupaten tanah datar)
Akuntansi Keperilakuan,

Jakarta, PT Raja Grfindo

Persada.

Indriantoro dan Supomo, 2002, Methodologi Penelitian Bisnis, Cetakan kedua, BPFE UGM, Yogyakarta.

Jones, R, 2000, Publik Sektor Accounting, $5^{\text {th }}$ ed, Prentice Hall.

Kunarjo, 2000, Perencanaan dan Pembiayaan Pembangunan, Edisi Ketiga, UI-Press, Jakarta.

Mangkoesubroto Guritno, 2001, Ekonomi Publik

Edisi Ketiga, BPFE-UGM, Yogyakarta.

Mardiasmo dan Wihana Kirana Jaya, 1999, Pengelolaan Keuangan Daerah yang Berorientasi Publik, Kompak No. 21, 385402.

Mardiasmi, 1999, Otonomi Daerah Berorientasi Kepada Kepentingan Publik, BPFEUGM, Yogyakarta.

Mardiasmo, Makhfatih, Supomo, B. Purwanto, H, 2002, Pengembangan Model Standar 
Analisis Belanja (SAB)

Anggaran Daerah (APBD),

Laporan Hasil Penelitian, PAU

SE-UGM, Yogyakarta.

Mardiasmo, 2002, Akuntansi Sektor

Publik, Andi, Yogyakarta.

Mardiasmo, 2002, Otonomi dan

Manajemen Keuangan Daerah, Andi, Yogyakarta.

Misni Erawati, 2009, Pengaruh Partisipasi Penyusunan

Anggaran Berbasis Kinerja (ABK) Terhadap Kinerja Kepala Satuan Kerja

Perangkat Daerah (SKPD)

Pemerintah Daerah Komitmen

Organisasi Dan Gaya

Kepemimpinan Sebagai

Variabel Modeating.

Mulyadi, 1999, Akuntansi Biaya, Edisi

Kelima, Aditya Media, Yogyakarta.

Mulyadi, 2001, Balance Scorecard Alat Manajemen Kontemporer Untuk Pelipat Ganda Kinerja Keuangan Perusahaan, Salemba Empat, Jakarta.

Nugroho Adi Utomo, 2007, Anggaran Berbasis Kinerja, Tantangan menuju tata kelola kehutanan yang baik, Departemen

Kehutanan RI.

Raharto Iman, 2008, Anggaran Berbasis Kinerja (Pelaksanaan Masalah dan Solusi di Indonesia) ,(Tesis).

Robin SP, 2003, Organizational Behavior, $10^{\text {th }}$,

New Jersey, Pearson

Edication Inc.

Santoso, Singgih, 2005, SPSS Statistik Parametrik,

Elex Media Komputindo, Jakarta.

Sugiri, Slamet, 1999, Akuntansi Manajemen, UPP AMP YKPN, Yogyakarta.

Sugiyono, 2012, Metodologi Penelitian Administrasi dilengkapi dengan metode $R \& D$, Edisi Revisi , Cetakan ke 20, Alfabeta, Bandung.

Sumodiningrat Gunawan, 2007, Ekonometrika,

BPFE Yogyakarta.

Suparmoko, M, 2000, Keuangan Negara Dalam Teori dan Praktek, BPFE, Yogyakarta. Soetrisno, 2010,Pengaruh Motivasi 


\author{
dan \\ pelimpahan \\ Wewenang \\ Dalam \\ Penyusunan Anggaran \\ Terhadap Kinerja Manajerial \\ (Tesis)
}

Suwandi, I Made, 2000, Sistem Pemerintahan Daerah di Indonesia, Bahan Kursus Keuangan Daerah Angkatan XII, UI, Jakarta.

Syamsi, Ibro, 1986, Keuangan Daerah

$$
\begin{array}{lcr}
\text { dalam } & \text { Pendapatan } & \text { Asli } \\
\text { Daerah, } & \text { Rajawali } & \text { Press, } \\
\text { Jakarta. } & & \\
& &
\end{array}
$$

Wildavsky, Aoron, 1975, Budgeting A Comparative Theory of Budgetary Processes. Boston: Little Brown and Company (Inc)

Wibowo, 2007, Manajemen Kinerja, Edisi Dua Penerbit PT Rajagrafindo Persada Jakarta

$$
\begin{aligned}
& \text { Peraturan Pemerintah Republik } \\
& \text { Indonesia Nomor 58,2005 } \\
& \text { tentang pengelolaan keuangan } \\
& \text { Daerah }
\end{aligned}
$$

Peraturan pemerintah Republik Indonesia nomor 8, 2006 tentan pelaporan Keuangan dan Kinerja Instansi Pemerintah.

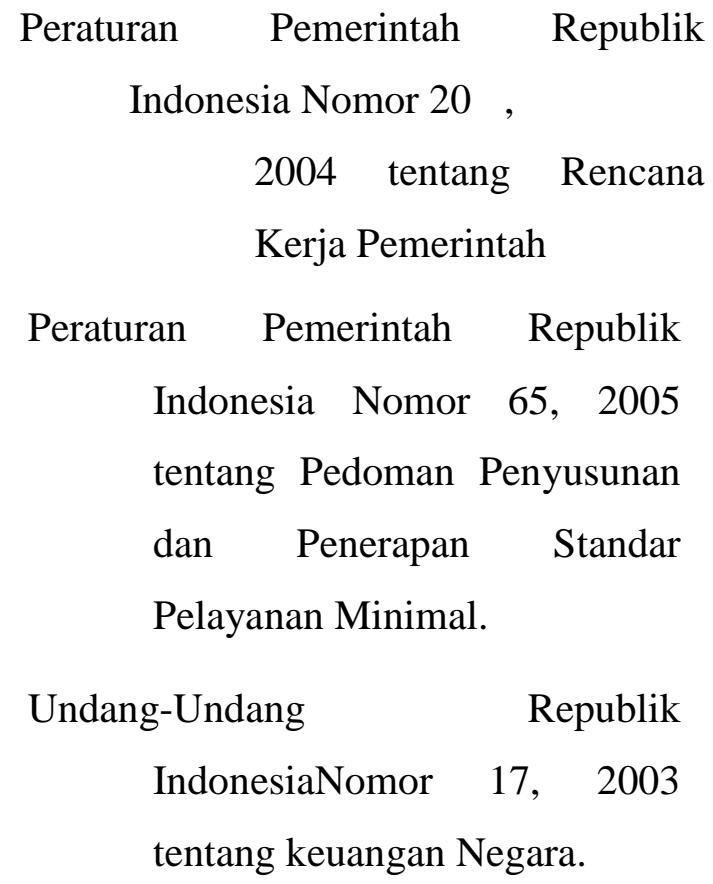

